\title{
Study of serum lipid profile and magnesium in preeclampsia
}

\author{
Hymavathi K. Reddy*, Vineela P., Bhargavi M. Chowdary
}

Department of Obstetrics and Gynecology, Narayana Medical College and Hospital, Nellore, Andhra Pradesh, India

Received: 08 October 2018

Accepted: 11 February 2019

\section{*Correspondence:}

Dr. Hymavathi K. Reddy,

E-mail: drhymakrreddy@yahoo.co.in

Copyright: ( ) the author(s), publisher and licensee Medip Academy. This is an open-access article distributed under the terms of the Creative Commons Attribution Non-Commercial License, which permits unrestricted non-commercial use, distribution, and reproduction in any medium, provided the original work is properly cited.

\section{ABSTRACT}

Background: A comparative study of serum lipid profile and magnesium levels in normal pregnancy versus preeclampsia (PE).

Methods: A prospective study done for 2 years (October 2014 to October 2016) in the Department of Obstetrics and Gynecology, Narayana medical college and hospital, a tertiary care centre, Nellore, Andhra Pradesh, India. A sample size of 200 pregnant women, recruited and divided into group A and B. group A being women with PE and group B is normal pregnant women.A10ml of venous blood was collected in the fasting state and serum collected from clotted blood to measure lipid profile, magnesium, Apo lipoprotein A-I and Apo lipoprotein B 100.Serum Lipid profile measured by enzymatic method using commercially available kit Human (GmbH Germany) using humastar 600 chemistry analyzer (Human GmbH Germany). Serum magnesium measured by dye binding method using commercially available kit Human (GmbH Germany) using Humastar 600 chemistry analyzer (Human GmbH Germany). Serum ApoA-I and ApoB were measured by immune-turbidometry using commercial kits from Spinreact Spain. Urine albumin done by dipstick method.

Results: Serum total cholesterol (TC), Triglyceride (TG), low density lipoprotein (LDL), very low-density lipoprotein (VLDL), Apo lipoprotein B 100 (Apo B100) were high and serum Magnesium, high density lipoprotein (HDL) and Apo lipoprotein A1(Apo A1) were low in the study group (group A) compared to controls (group B).

Conclusions: Abnormal lipid profile (low HDL and increased TG concentration) and serum hypomagnesaemia may be contributing etiologies of preeclampsia, having good predictive value as a screening procedure for PE in high risk pregnant population.

Keywords: High density lipoprotein, Lipid profile, Preeclampsia-serum lipids-magnesium, Serum total cholesterol

\section{INTRODUCTION}

Hypertension during pregnancy is one of the leading causes of maternal and perinatal morbidity and mortality. ${ }^{1}$ It is a relatively common complication of pregnancy affecting $2-5 \%$ of women globally. ${ }^{2}$ Preeclampsia in India ranges from $5 \%$ to $15 \%$, contributing to $16 \%$ of maternal mortality and $20 \%$ of perinatal mortality with dreaded pregnancy complications viz eclampsia and cerebrovascular accidents. The pathophysiology of preeclampsia is still unclear. However, studies have demonstrated an association with a cluster of metabolic abnormalities. According to epidemiological evidence women with previous gestational hypertension seem to be at increased risk of hypertension, cardiovascular disease, stroke and death from ischaemic heart disease in later life. ${ }^{1}$

Several clinical and biochemical screening tests have been employed to determine women at risk of developing 
this disease, but no single test can reliably predict the possibility of developing the disease in pregnancy. ${ }^{3}$ Since abnormal lipid metabolism seems important in the pathogenesis of preeclampsia, assessment of serum lipid profile in pregnant women at risk of this disease may suggest some new diagnostic or prognostic tools.

It is a well-known fact that electrolytes play an important role in the etiopathogenesis of hypertension. Magnesium has been established as an essential element for fetal well-being. Its deficiency during pregnancy has been reported to be associated with pre-eclampsia, eclampsia, preterm birth and intra uterine growth restriction.,

Magnesium modulates the cardiovascular effect of sodium and potassium and it is the co-factor for the sodium potassium ATPase activity. Since it contributes significantly in the functioning of the vascular smooth muscles, the present study was designed to evaluate this electrolyte in preeclampsia.

The main objective of this study was to compare the lipid profile and serum magnesium in preeclamptic and normal pregnant women. Moreover, the hormonal imbalance is a prime factor for the etiopathogenesis of $\mathrm{PE}$ and this endocrinal imbalance is well reflected in alteration of serum lipid profile. Therefore, simple measurements of serum lipid parameters may be of good predictive value in toxaemia of pregnancy, avoiding the costly investigations.

\section{METHODS}

A prospective study done in the Department of Obstetrics and Gynaecology, Narayana medical college and Hospital, Nellore for a period of 2 years.

This study was designed to look for any differences of serum lipid profile and serum magnesium levels in preeclampsia and in normal pregnancy.

A sample size of 200 women divided into 2 groups, 100 in each group were recruited. Group A being women with $\mathrm{PE}$ and group $\mathrm{B}$ is normal pregnant women. Institutional ethical committee clearance and informed consent of all the recruited population was obtained.

\section{Inclusion criteria}

- Pregnant women aged 18-35 years with BP $\geq 140 / 90 \mathrm{~mm} \mathrm{Hg}$ and gestational age above 20 weeks with proteinuria were recruited as study population along with age and parity matched normal pregnant women as controls.

\section{Exclusion criteria}

- Women who were having pre-existing hypertension, renal disease and previous history of convulsions were excluded.
All the women in the study were evaluated with detailed history, complete systemic and obstetric examination. Apart from routine antenatal investigations, serum magnesium levels and serum lipid profile (serum cholesterol, serum triglycerides, serum VLDL, serum LDL, serum HDL, serum apolipoprotein B100 and serum apolipoprotein A1) was done for all the women. In the fasting state with $10 \mathrm{ml}$ of venous blood being collected, allowed to clot to obtain the serum.

Serum lipid profile (total cholesterol, HDL-cholesterol, LDL-cholesterol and triglycerides) was measured by enzymatic method using commercially available kit Human (GmbH Germany) using Humastar 600 chemistry analyzer (Human GmbH Germany). Serum magnesium measured by dye binding method using commercially available kit Human (GmbH Germany) using Humastar 600 chemistry analyzer (Human GmbH Germany). Serum ApoA-I and ApoB were measured by immuneturbidometry using commercial kits from spin react Spain. Urine albumin was done by dipstick method.

\section{RESULTS}

A total of 200 pregnant women were recruited into the study and divided into A and B groups. Group A constitutes the study population (preeclamptic women) and group B the controls (normal pregnant women). The age and mean gestational age were closely matching in both the groups.

Table 1: Age distribution-study group versus controls.

\begin{tabular}{|l|l|l|}
\hline Age & Study group & Control group \\
\hline $18-22$ & 38 & 42 \\
\hline $23-27$ & 46 & 46 \\
\hline $28-32$ & 11 & 10 \\
\hline$>32$ & 5 & 2 \\
\hline
\end{tabular}

Present study showed that there was no significant difference in the mean age of study and control groups. The mean age of study group being $23.97 \pm 4.32$ years and that of controls was $23.84 \pm 3.34$ years (Table 1 ). In study group 53 were primigravidae and 47 were multiparous women whereas in controls the corresponding figures are 28 and 72 (Table 2).

Table 2: Parity-study group versus controls.

\begin{tabular}{|l|l|l|l|}
\hline Gravida & $\begin{array}{l}\text { Study } \\
\text { group }\end{array}$ & $\begin{array}{l}\text { Control } \\
\text { group }\end{array}$ & Total \\
\hline $\begin{array}{l}\text { Primi } \\
\text { gravida }\end{array}$ & 53 & 28 & 81 \\
\hline $\begin{array}{l}\text { Multi } \\
\text { gravida }\end{array}$ & 47 & 72 & 119 \\
\hline
\end{tabular}

There was a significant difference in the mean arterial pressures between study and control groups with significant $\mathrm{P}$ value (Table 3 ). 
Table 3: Mean arterial pressure (MAP)-study group versus controls.

\begin{tabular}{|c|c|c|c|}
\hline & Study group & Control group & p value \\
\hline MAP (mm of $\mathrm{Hg})$ & $153.2 \pm 14.793$ & $110.67 \pm 7.77$ & $<0.0001$ \\
\hline
\end{tabular}

\begin{abstract}
Albuminuria was found in the entire study group-32 women had $1 \pm 27$ women had $2 \pm 18$ women had $3 \pm$ and 23 women had traces whereas the corresponding figures in the controls being 2,3,0,1 respectively and 94 with no albuminuria at all (Table 4).
\end{abstract}

Serum total cholesterol, triglycerides, low density lipoproteins, very low-density lipoproteins, and Apo lipoprotein B 100 were high in the study group compared to controls with significant $p$ value (Table 5). Serum magnesium, high density lipoproteins and Apo lipoprotein A1 were found to be low in the study group compared to controls with the $\mathrm{p}$ values being significant (Table 5).

Table 4: Urine albumin-study group versus controls.

\begin{tabular}{|l|l|l|}
\hline Urine albumin & Study group & Control group \\
\hline NIL & 0 & 94 \\
\hline TRACES & 23 & 1 \\
\hline $1+$ & 32 & 2 \\
\hline $2+$ & 27 & 3 \\
\hline $3+$ & 18 & 0 \\
\hline
\end{tabular}

Table 5: Mean values of lipid profile-study versus controls and mean values of serum magnesium and lipid profilestudy versus controls.

\begin{tabular}{|l|l|l|l|}
\hline Parameter & Study group & Control group & p value \\
\hline S. TC $(\mathrm{mg} / \mathrm{dl})$ & $208.11 \pm 8.987$ & $164.12 \pm 4.482$ & $<0.0001$ \\
\hline S. TG $(\mathrm{mg} / \mathrm{dl})$ & $204.4 \pm 8.865$ & $153.05 \pm 12.245$ & $<0.0001$ \\
\hline S. LDL-C $(\mathrm{mg} / \mathrm{dl})$ & $142.48 \pm 6.295$ & $114.4 \pm 7.897$ & $<0.0001$ \\
\hline S. VLDL-C $(\mathrm{mg} / \mathrm{dl})$ & $52.05 \pm 4.384$ & $36.04 \pm 1.922$ & $<0.0001$ \\
\hline APO B100 $(\mathrm{mg} / \mathrm{dl})$ & $48.34 \pm 9.83$ & $37.67 \pm 4.57$ & $<0.0001$ \\
\hline S. Mg $(\mathrm{mg} / \mathrm{dl})$ & $1.39 \pm 1.46$ & $2.09 \pm 2.01$ & $<0.0001$ \\
\hline S. HDL-C $(\mathrm{mg} / \mathrm{dl})$ & $37.99 \pm 2.393$ & $49.21 \pm 2.840$ & $<0.0001$ \\
\hline Apo Lipoprotein A1 $(\mathrm{mg} / \mathrm{dl})$ & $132.26 \pm 11.58$ & $170.56 \pm 16.33$ & $<0.0001$ \\
\hline
\end{tabular}

\section{DISCUSSION}

Preeclampsia continues to be a major obstetric problem in present-day healthcare practice. It affects not only maternal health but also puts the fetus at risk. In women with PE, free fatty acids especially linolenic acid and TG concentrations are elevated in blood which is found to be increased even before 20 weeks of gestation and thus predicts PE. ${ }^{6}$ In endothelial cells oxidative stress is stimulated by linolenic acid causing excessive lipid peroxidation and thereby decreasing antioxidant activity, which may result in an imbalance between peroxidases and antioxidants. Several investigators have hypothesized that the disordered lipid profile and oxidative stress in endothelial cell is of major importance to the pathophysiology of preeclampsia. ${ }^{7}$

Maternal age is one of the essential risk factors in changing lipid metabolism in women with preeclampsia. As per the study of Sajith $\mathrm{M}$ et al, maximum number of women were seen in age group of $18-22$ years $(40.5 \%)$ with least number being in the group of more than 32 years $(2.7 \%){ }^{8}$ In the present study majority of women were seen in the age group of 23-27years (Table 6).

Table 6: Age distribution of preeclamptic women.

\begin{tabular}{|l|l|l|l|l|}
\hline Study & 18-22years $\mathrm{n} / \%$ & $23-27$ years $\mathrm{n} / \%$ & $28-32$ years $\mathrm{n} / \%$ & $>32$ years $\mathrm{n} / \%$ \\
\hline Sajith M et al & (30/40.5 & $28 / 37.8$ & $14 / 18.9$ & $2 / 2.7$ \\
\hline Present study & $38 / 38$ & $46 / 46$ & $11 / 11$ & $5 / 5$ \\
\hline
\end{tabular}


They were found to be career oriented and got married late which could be the cause for higher percentage in this age group. It is a well-known fact that primiparity almost triples the risk for preeclampsia. The above studies show that more Primigravidae were Preeclamptic compared to multigravidae. Present study results were also in par with above. Among multigravidae the parity of $74.4 \%$ of women was 2 and the rest $25.5 \%$ were of higher parity thus proving the risk of developing PE gets reduced as parity increases (Table 7).

Table 7: Parity distribution of preeclamptic women.

\begin{tabular}{|l|l|l|}
\hline Study & Primigravida & Multigravida \\
\hline${\text { Prakash } \mathrm{J} \text { et } \mathrm{al}^{9}}^{9}$ & 20 & 12 \\
\hline Sajith $\mathrm{M}$ et $\mathrm{al}^{8}$ & 38 & 36 \\
\hline Present study & 53 & 47 \\
\hline
\end{tabular}

The major modulator of hypertriglyceridemia is oestrogen as pregnancy is linked with hyper oestrogenaemia. Oestrogen induces hepatic biosynthesis of endogenous triglycerides, which is carried by hepatic VLDL into the circulation. ${ }^{10}$ In PE, increased Triglycerides are found to be deposited in predisposed vessels, such as uterine spiral arteries leading to endothelial dysfunction. In studies done by Jayanta De et al, Islam NAF et al and Nazil R et al, it is found that the mean serum TG, serum total cholesterol, low density lipoproteins and Apo protein B 100 values were high where as that of HDL and Apo protein A1 were low in study group compared to control group which was statistically significant. The present study results are also found to have the same pattern (Table 8 and 9). But in the study by Nazil $R$ et al there was not found much difference in LDL levels in both study and control groups.

Table 8: Comparative studies of lipid profile in pre-eclampsia.

\begin{tabular}{|c|c|c|c|c|c|c|c|c|}
\hline \multirow[t]{2}{*}{ Study } & \multicolumn{2}{|c|}{$\begin{array}{l}\text { Serum triglycerides } \\
\text { (mg/DI)- } \\
\text { mean values }\end{array}$} & \multicolumn{2}{|c|}{$\begin{array}{l}\text { Serum total } \\
\text { cholesterol (mg/dl)- } \\
\text { mean values }\end{array}$} & \multicolumn{2}{|c|}{$\begin{array}{l}\text { Serum high density } \\
\text { lipoproteins (mg/DI)- } \\
\text { mean values }\end{array}$} & \multicolumn{2}{|c|}{$\begin{array}{l}\text { Serum low density } \\
\text { lipoproteins (mg/DI)- } \\
\text { mean values }\end{array}$} \\
\hline & $\begin{array}{l}\text { Study } \\
\text { group }\end{array}$ & $\begin{array}{l}\text { Control } \\
\text { group }\end{array}$ & $\begin{array}{l}\text { Study } \\
\text { group }\end{array}$ & $\begin{array}{l}\text { Control } \\
\text { group }\end{array}$ & $\begin{array}{l}\text { Study } \\
\text { group }\end{array}$ & $\begin{array}{l}\text { Control } \\
\text { group }\end{array}$ & $\begin{array}{l}\text { Study } \\
\text { group }\end{array}$ & $\begin{array}{l}\text { Control } \\
\text { group }\end{array}$ \\
\hline Jayanta D et al ${ }^{11}$ & $\begin{array}{l}275.6 \pm \\
38.93\end{array}$ & $\begin{array}{l}215.6 \pm \\
38.96\end{array}$ & $\begin{array}{l}236.3 \pm \\
35.63\end{array}$ & $\begin{array}{l}219.0 \pm \\
16.6\end{array}$ & $\begin{array}{l}45.9 \pm \\
8.00\end{array}$ & $\begin{array}{l}60.7 \pm \\
8.11\end{array}$ & $\begin{array}{l}135.4 \pm \\
23.36\end{array}$ & $\begin{array}{l}114.2 \pm \\
11.32\end{array}$ \\
\hline Islam NAF et al ${ }^{12}$ & $\begin{array}{l}225.6 \pm \\
28.93\end{array}$ & $\begin{array}{l}165.6 \pm \\
17.22\end{array}$ & $\begin{array}{l}186.3 \pm \\
34.43\end{array}$ & $\begin{array}{l}169.1 \pm \\
7.03\end{array}$ & $\begin{array}{l}42.4 \pm \\
9.29\end{array}$ & $\begin{array}{l}55.7 \pm \\
7.11\end{array}$ & $\begin{array}{l}134.4 \pm \\
24.26\end{array}$ & $\begin{array}{l}115.2 \pm \\
10.72\end{array}$ \\
\hline Nazli R et al ${ }^{13}$ & $\begin{array}{l}259.05 \pm \\
10.0\end{array}$ & $\begin{array}{l}212.3 \pm \\
7.28\end{array}$ & $\begin{array}{l}209.76 \pm \\
5.59\end{array}$ & $\begin{array}{l}202.23 \pm \\
4.6\end{array}$ & $\begin{array}{l}45.98 \pm \\
1.08\end{array}$ & $\begin{array}{l}52.2 \pm \\
1.14\end{array}$ & $\begin{array}{l}111.3 \pm \\
5.26\end{array}$ & $\begin{array}{l}107.4 \pm \\
4.07\end{array}$ \\
\hline Present study & $\begin{array}{l}204.4 \pm \\
8.865\end{array}$ & $\begin{array}{l}153.05 \pm \\
12.24\end{array}$ & $\begin{array}{l}208.11 \pm \\
8.98\end{array}$ & $\begin{array}{l}164.12 \pm \\
4.482\end{array}$ & $\begin{array}{l}37.99 \pm \\
2.393\end{array}$ & $\begin{array}{l}49.21 \pm \\
2.840\end{array}$ & $\begin{array}{l}142.48 \pm \\
6.29\end{array}$ & $\begin{array}{l}114.4 \pm \\
7.897\end{array}$ \\
\hline
\end{tabular}

Table 9: Comparative studies of serum Apo Lipo A1 and Apo B1 in study and control groups.

\begin{tabular}{|c|c|c|c|c|}
\hline \multirow{2}{*}{ Study } & \multicolumn{2}{|c|}{ Serum Apo Lipo A1 (mg/DI)- mean values } & \multicolumn{2}{|c|}{ Serum Apo B100 (mg/DI)-mean values } \\
\hline & Study group & Control group & Study group & Control group \\
\hline Nazli $R$ et al ${ }^{13}$ & $177.86 \pm 5.67$ & $190.14 \pm 5.31$ & $120.06 \pm 4.32$ & $128.33 \pm 5.50$ \\
\hline Present study & $132.26 \pm 11.58$ & $170.56 \pm 16.33$ & $48.3 \pm 9.83$ & $37.67 \pm 4.57$ \\
\hline
\end{tabular}

Table 10: Lipid profile ratios-study versus controls.

\begin{tabular}{|l|l|l|l|l|l|l|l|l|}
\hline Study & $\begin{array}{l}\text { Serum LD } \\
\text { Study } \\
\text { group }\end{array}$ & $\begin{array}{l}\text { Control } \\
\text { group }\end{array}$ & $\begin{array}{l}\text { Study } \\
\text { group }\end{array}$ & $\begin{array}{l}\text { Control } \\
\text { group }\end{array}$ & $\begin{array}{l}\text { Study } \\
\text { group }\end{array}$ & $\begin{array}{l}\text { Control } \\
\text { group }\end{array}$ & $\begin{array}{l}\text { Study } \\
\text { group }\end{array}$ & $\begin{array}{l}\text { Control } \\
\text { group }\end{array}$ \\
\hline $\begin{array}{l}\text { Jayanta D } \\
\text { et al }\end{array}$ & $2.89 \pm 0.50$ & $1.72 \pm 0.62$ & $5.19 \pm 0.56$ & $3.64 \pm 0.35$ & $6.09 \pm 1.01$ & $3.6 \pm 0.51$ & $0.84 \pm 0.12$ & $1.42 \pm 0.22$ \\
\hline $\begin{array}{l}\text { Nazli R } \\
\text { et al }\end{array}$ & $2.76 \pm 0.16$ & $2.07 \pm 0.29$ & $5.38 \pm 0.19$ & $3.95 \pm 0.36$ & $8.38 \pm 0.5$ & $4.41 \pm 0.43$ & $0.72 \pm 0.03$ & $1.3 \pm 0.09$ \\
\hline $\begin{array}{l}\text { Present } \\
\text { study }\end{array}$ & $3.76 \pm 0.29$ & $2.33 \pm 0.24$ & $5.5 \pm 0.46$ & $3.34 \pm 0.21$ & $5.4 \pm 0.45$ & $3.11 \pm 0.29$ & $0.74 \pm 0.084$ & $1.37 \pm 0.102$ \\
\hline
\end{tabular}

The ratios of lipid profiles have also been calculated (TC/HDL, TG/HDL, LDL/HDL and HDL/ VLDL) in the present study. The values of these lipid profile ratios followed the same pattern as individual lipid levels (Table 10). The ratios of LDL/HDL, TC/HDL, TG/HDL are found higher and HDL/ VLDL ratio are found lower 
in study group compared to controls as expected. Though the association of these ratios in pregnancy and PE is yet to be recognized, the significance of altered TC/HDL, TG/HDL, LDL/HDL and HDL/ VLDL ratios cannot be ignored as they point towards more threat of PE.

\section{Serum magnesium}

Pregnancy is a state of magnesium depletion. The total and ionized magnesium levels are significantly lower in normal pregnancy compared to non-pregnant women. ${ }^{14,15}$ The levels tend to fall during pregnancy and further decrease in women who develop preeclampsia later.15 The utilization of magnesium during pregnancy exceeds the intake creating a state of physiological hypomagnesemia. ${ }^{16}$ Serum magnesium progressively declines during pregnancy reaching a nadir at 34 weeks and then rises up to term. ${ }^{17}$ Statistically significant fall in serum magnesium has been observed in pre-eclampsia and with remarkable reduction in eclampsia. ${ }^{18}$ In study done by Indumathi $\mathrm{V}$ et al, serum magnesium decreased in the study group when compared to control group which was significant. But in the study by Deepa V et al, Kanagal serum magnesium levels were not significantly altered in both the groups. In present study the serum Magnesium levels were found to show a downward trend in preeclamptic compared to controls which was significant (Table 11).

Table 11: Serum magnesium levels-study versus controls.

\begin{tabular}{|c|c|c|c|}
\hline \multirow{2}{*}{ Study } & \multicolumn{2}{|c|}{$\begin{array}{c}\text { Serum magnesium } \\
(\mathrm{mg} / \mathrm{Dl})\end{array}$} & \multirow{2}{*}{$P$ value } \\
\hline & $\begin{array}{l}\text { Study } \\
\text { group }\end{array}$ & $\begin{array}{l}\text { Control } \\
\text { group }\end{array}$ & \\
\hline Indumathi $\mathrm{V}$ et al ${ }^{19}$ & $1.35 \pm 0.17$ & $2.63 \pm 0.22$ & $<0.0001$ \\
\hline Kanagal DV et al ${ }^{20}$ & $1.43 \pm 0.55$ & $1.57 \pm 0.72$ & NS \\
\hline Present study & $1.39 \pm 0.146$ & $2.09 \pm 0.201$ & $<0.0001$ \\
\hline
\end{tabular}

\section{CONCLUSION}

Abnormal lipid metabolism predominantly low HDL-C and high TG concentrations increase the vascular dysfunction and oxidative stress seen in PE. Hence the serum lipid profile has to be done during antenatal care as it is very helpful in early detection and treatment of hypertensive disorders amongst pregnant population. The decreased serum magnesium level is one of the predictors for the development of PE in pregnant women. Hence screening of all the high-risk antenatal population for serum dyslipidemia and hypomagnesemia may help in predicting and reducing the development of later complications of Preeclampsia.

\section{Funding: No funding sources}

Conflict of interest: None declared

Ethical approval: The study was approved by the Institutional Ethics Committee

\section{REFERENCES}

1. Evrüke IC, Demir SC, Ürünsak IF, Özgünen FT, Kadayıfçı O. Comparison of lipid profiles in normal and hypertensive pregnant women. Annals Saudi Med.2004;24(5):382.

2. Karar T, Fattah MA, Alenazy KR, Alharbi MJ, Alqahtani FM, Al Tamimi W, et al. Assessment of biochemical changes in pregnancy induced hypertension among Saudi population at KAMCRiyadh.

3. Jammalamadaga VS, Abraham P. Abnormal lipid metabolism is associated with angiogenic and antiangiogenic factor imbalance in PIH women. Int $\mathbf{J}$ Reprod Contracept Obstet Gynecol.2017;6(9):3984.

4. Jain S, Sharma P, Kulshreshtha S, Mohan G, Singh $\mathrm{S}$. The role of calcium magnesium and zinc in preeclampsia. Biol Trace Element Res. 2010;133(2):162-70.

5. Markrides M, Crowther CA. Magnesium supplementation in pregnancy(review). Cochrane Database syst Rev 2012;10.

6. Oken E, Ning YI, Rifas-Shiman SL, Rich-Edwards JW, Olsen SF, Gillman MW. Diet during pregnancy and risk of preeclampsia or gestational hypertension. Annals Epidemiol. 2007;17(9):663-8.

7. Kashinakunti SV, Sunitha H, Gurupadappa K, Shankarprasad DS, Suryaprakash G, Ingin JB. Lipid peroxidation and antioxidant status in preeclampsia. Al Ameen J Med Sci. 2010;3(1):38-41.

8. Sajith M, Nimbargi V, Modi A, Sumariya R, Pawar A. Incidence of pregnancy induced hypertension and prescription pattern of antihypertensive drugs in pregnancy. Int J Pharma Sci Res. 2014;23:4.

9. Prakash J, Pandey LK, Singh AK, Kar B. Hypertension in Pregnancy-Hospital Based Study. J Assoc Physic India. 2006;54®:273.

10. Adegoke OA, lyare EE, Gbenebitse SO. Fasting plasma glucose and cholesterol levels in pregnant Nigerian women. Niger. Postgraduate Med.J.2003;10:32-6.

11. Jayanta D, Mukhopadhyay A, Pradip KS. Study of serum lipid profile in pregnancy induced hypertension. Ind J of Clin Biochem. 2006;21:165-8.

12. Islam NA, Chowdhury MA, Kibria GM, Akhter S. Study of serum lipid profile in pre-eclampsia and eclampsia. Faridpur Med College J. 2010;5(2):56-9.

13. Nazli R, Khan MA, Akhtar T, Lutfullah G, Mohammad NS, Ahmad J, et al. Abnormal lipid levels as a risk factor of eclampsia, study conducted in tertiary care Hospitals of Khyber Pakhtunkhwa Province-Pakistan. Pak J Med Sci. 2013;29(6):1410.

14. Bardicef M, Bardicef O, Sorokin Y, Altura BM, Altura BT, Cotton DB, et al. Extracellular and intracellular magnesium depletion in pregnancy and gestational diabetes. Am J Obstetr Gynecol.1995;172(3):1009-13.

15. Standley CA, Whitty JE, Mason BA, Cotton DB. Serum ionized magnesium level in normal and 
preeclamptic gestation. Obstet Gynaecol. 1997:89:24-31.

16. Semczuk M, Semczuk-Sikora A. New data on toxic metal intoxication $(\mathrm{Cd}, \mathrm{Pb}$, and $\mathrm{Hg}$ in particular) and $\mathrm{Mg}$ status during pregnancy. Med Sci Monitor. 2001;7(2):332-40.

17. Bandebuche S, Sagade B, Sontakke A. Serum magnesium in pregnancy induced hypertension. Int $\mathbf{J}$ Res Med Sci. 2013;1:413-6.

18. Patil VP, Choudhari NA. A study of serum magnesium in pre-eclampsia and eclampsia. Indian $\mathrm{J}$ Clinic Biochemist. 1991;6(2):69-72.

19. Indumati V, Kodliwadmath M V, Sheela M K. The role of serum electrolytes in pregnancy induced hypertension. J Clin Diag Res. 2011:5(1):66-9.
20. Kanagal DV, Rajesh A, Rao K, Devi UH, Shetty H, Kumari S, et al. Levels of serum calcium and magnesium in pre-eclamptic and normal pregnancy: A study from Coastal India. J Clin Diag Res. 2014;8(7):OC01.

Cite this article as: Reddy $\mathrm{HK}$, Vineela $\mathrm{P}$,

Chowdary BM. Study of serum lipid profile and magnesium in preeclampsia. Int J Reprod Contracept Obstet Gynecol 2019;8:1445-50. 